\title{
SYNTHESIS, PHOTOPHYSICAL, ELECTROCHEMICAL AND DNA BINDING PROPERTIES OF A NOVEL RUTHENIUM(II) $\mathrm{N}^{\wedge} \mathrm{N}$ COMPLEX
}

\author{
Jianfei KONG, ${ }^{*}$ Jun CHEN and Liying JIANG \\ Jiangsu Vocational College of Medicine. No. 283, South Jiefang Road, Yancheng 224000, Jiangsu, China
}

A novel mononuclear ruthenium(II) $\mathrm{N}^{\wedge} \mathrm{N}$ complex of the type $\left[\mathrm{Ru}(\mathrm{bpy})_{2}\left(\mathrm{~N}^{\wedge} \mathrm{N}\right)\right]\left(\mathrm{PF}_{6}\right)_{2}$ where bpy $=2,2^{\prime}$-bipyridine and $\mathrm{N}^{\wedge} \mathrm{N}=\mathrm{N}$ - $(2$ pyridylmethylene)-2-anthramine) has been synthesized and characterized. Its electronic absorption, luminescence and electrochemical properties were investigated and discussed in details. The interactions of the ruthenium(II) complex with calf thymus DNA were investigated by

UV-visible spectra as well as emission spectra, the results of binding experiments displayed that this complex is able to interact with calf thymus DNA with a moderate binding constant of $1.06 \times 10^{4} \mathrm{dm}^{3} \mathrm{~mol}^{-1}$ or $1.43 \times 10^{4} \mathrm{dm}^{3} \mathrm{~mol}^{-1}$.

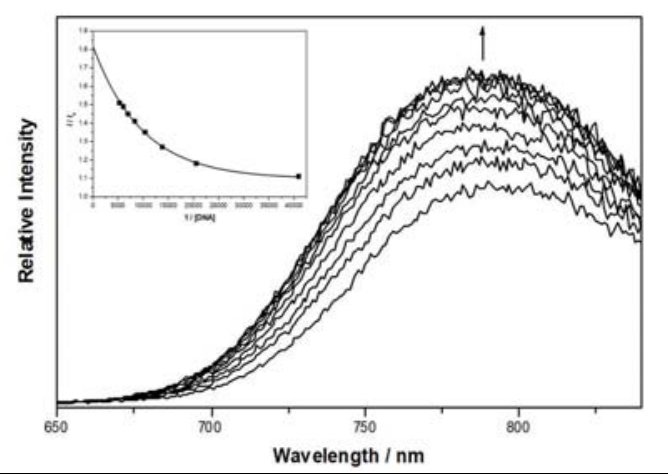

\section{INTRODUCTION}

Since the reports on the highly luminescent DNA light switch behaviour of $\left[\mathrm{Ru}(\mathrm{bpy})_{2}(\mathrm{dppz})\right]^{2+}$ $(\mathrm{dppz}=$ dipyrido[3,2-a:2',3'-c]phenazine $),{ }^{1}$ the binding of transition metal complexes to DNA has received much attention and extensive studies in the field of spectrochemical DNA recognition have emerged. ${ }^{2-4}$ These studies contribute to the design of conformation- or site-specific probes with emphasis on the use of cations with extended aromatic systems such as the dyes ethidium bromide, acridine orange cation, or proflavine, so as to enhance non-covalent binding especially through intercalation, or covalently linked bifunctional compounds for recognition of the biopolymer structure, the development of selective DNA cleaving agents for mapping or footprinting experiments, as well as rational drug design. DNA intercalation is a noncovalent binding mode by

\footnotetext{
* Corresponding author: lntukjf@163.com
}

which the dye slides between the hydrophobic base pairs of the polynucleotide duplex and is stabilized through $\pi$ stacking, as well as nonspecific ion interactions. Neutral cis-dichloro platinum complexes can also bind covalently to DNA by coordination to its nitrogen bases, whereas metal hexaammine complex cations such as those of cobalt and ruthenium bind to DNA via electrostatic and hydrogen-bonding interactions.

Positively charged octahedral transition metal (such as $\mathrm{Ru}, \mathrm{Pt}, \mathrm{Co}$ or $\mathrm{Zn}$ ) complexes with polypyridyl ligands often bind electrostatically to DNA at low ionic strength and also to the major groove of the DNA helix through stacking of one of the ligands with sufficiently extended structure between the base pairs. ${ }^{5}$ Photo-initiated electron transfer from the metal to a molecule of DNA mediated through the aromatic moiety has been observed for a number of complexes, such as $\left[\mathrm{Rh}(\mathrm{phen})_{3}\right]^{3+} \quad($ phen $=1,10$-phenanthroline), $\left[\mathrm{Co}\left(\mathrm{NH}_{3}\right)_{6}\right]^{3+}$ and $\left[\mathrm{Ru}(\mathrm{bpy})_{3}\right]^{2+}$. 


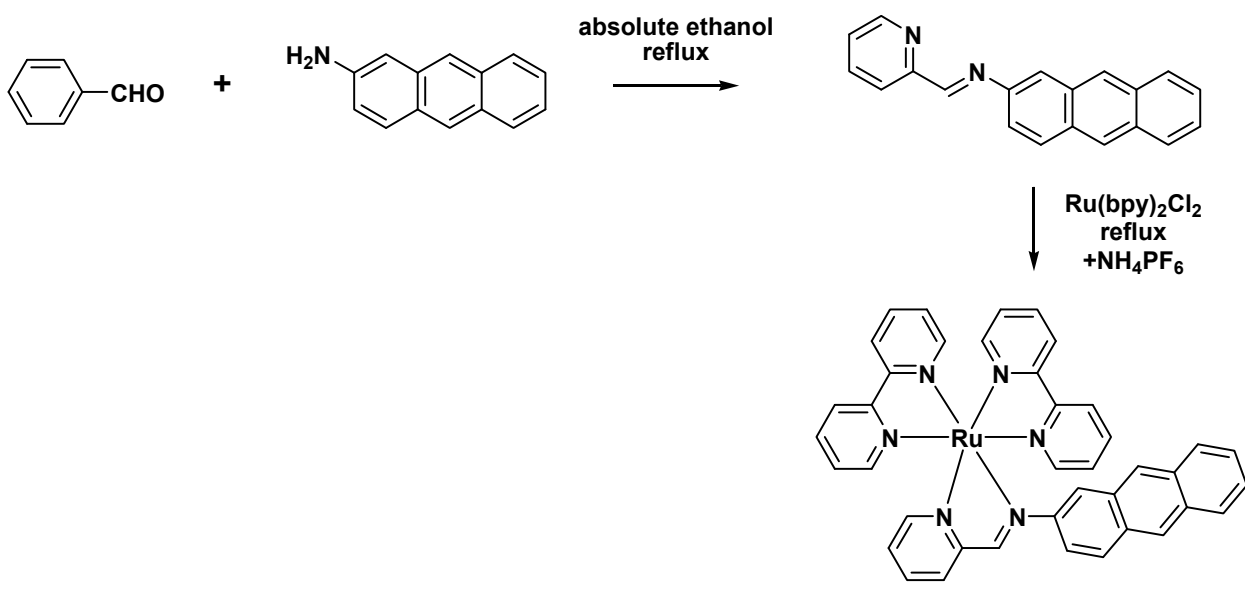

1

Fig. 1 - Synthetic route and the molecular structure of ruthenium $\mathrm{N}^{\wedge} \mathrm{N}$ complex $\mathbf{1}$.

In general, intercalators are planar, and planarity was suggested to be one of the most important features needed for efficient intercalation into the DNA helix. Large, planar, hydrophobic extended aromatic structures are expected to facilitate intercalation of the probe into the relatively nonpolar interior of the DNA helix. However, poor solubility of such moieties in water might reduce their usefulness. Therefore, they are incorporated into transition metal complexes, which are expected to have higher solubility in water and improved DNA binding affinity due to the increased electrostatic attraction between the probe and the DNA phosphates. Ruthenium(II) polypyridyl complexes have been shown to serve as good spectrochemical, luminescence and photochemical probes of various environments. ${ }^{6}$ They display intense metal-to-ligand-charge transfer (MLCT) absorption in the visible region and luminescence in the red, leading to easy detection of spectral changes.

\section{EXPERIMENTAL}

cis-[Ru(bpy $\left.)_{2} \mathrm{Cl}_{2}\right]$ was prepared according to a literature method. $^{7} \quad$ Tetrabutylammonium hexafluorophosphate $\left({ }^{\mathrm{n}} \mathrm{Bu}_{4} \mathrm{NPF}_{6}\right)$ (Aldrich, $98 \%$ ) was purified by recrystallization from ethanol three times before use. All other reagents were purchased of analytical grade and used as received.

\section{Synthesis of 1 [Ru(bpy) $)_{2}(N$-(2-pyridylmethylene)-2- anthramine $)]\left(\mathrm{PF}_{6}\right)_{2}$}

To a refluxing ethanolic solution of 2-aminoanthracene $(81.7 \mathrm{mg}, 0.42 \mathrm{mmol})$ was added 2-pyridinecarboxaldehyde ( $45.3 \mathrm{mg}, 0.42 \mathrm{mmol})$. The solution was heated and stirred for 5 minutes before cis-[Ru(bpy $\left.{ }_{2} \mathrm{Cl}_{2}\right](200 \mathrm{mg}, 0.38 \mathrm{mmol})$ was added. The mixture was refluxed overnight under nitrogen. After cooling to room temperature, the solution was filtered and reduced in volume. A saturated solution of $\mathrm{NH}_{4} \mathrm{PF}_{6}$ in methanol was added and the product was obtained by filtration. Subsequent recrystallization by vapour diffusion of diethyl ether into an acetonitrile solution of the complex gave the product as dark red crystals. Yield: $75 \%$. ${ }^{1} \mathrm{H}$ NMR $(400 \mathrm{MHz}$, $\left.\mathrm{CDCl}_{3}\right): \delta 7.0(\mathrm{~m}, 1 \mathrm{H}), 7.3-8.5(\mathrm{~m}, 24 \mathrm{H}), 8.6(\mathrm{~d}, J=5 \mathrm{~Hz}, 1 \mathrm{H})$, $8.9(\mathrm{t}, J=8 \mathrm{~Hz}, 2 \mathrm{H}), 9.1(\mathrm{~d}, J=5 \mathrm{~Hz}, 1 \mathrm{H}), 9.6(\mathrm{~s}, 1 \mathrm{H})$. Elemental analysis, $\left[\mathrm{C}_{40} \mathrm{H}_{30} \mathrm{~N}_{6} \mathrm{RuP}_{2} \mathrm{~F}_{12} \cdot 2\left(\mathrm{H}_{2} \mathrm{O}\right)\right]$, Calc. (found) \%: C 47.02 (47.05), H 3.35 (3.07), N 8.23 (8.21).

All spectroscopic titrations were carried out in aerated 5\% aqueous buffered methanolic solutions. The wavelengths with maximum changes in absorption and emission titrations were chosen to calculate the binding constants. The calf thymus DNA concentration per nucleotide was determined by uv-vis absorption spectroscopy at $260 \mathrm{~nm}$ using the molar extinction coefficient of $6600 \mathrm{dm}^{3} \mathrm{~mol}^{-1} \mathrm{~cm}^{-1}$.

The intrinsic binding constants $K$ of the ruthenium(II) complex 1 with calf thymus DNA can be determined from the equation,

$$
\frac{D}{\Delta \varepsilon_{a p}}=\frac{D}{\Delta \varepsilon}+\frac{1}{\Delta \varepsilon K}
$$

where $D$ is the concentration of calf thymus DNA, $\Delta \varepsilon_{\mathrm{ap}}=\left(\varepsilon_{\mathrm{a}}-\varepsilon_{\mathrm{f}}\right)$ and $\Delta \varepsilon=\left(\varepsilon_{\mathrm{b}}-\varepsilon_{\mathrm{f}}\right)$. The apparent extinction coefficient, $\varepsilon_{\mathrm{a}}$ is obtained from the ratio of $A_{\mathrm{obs}}$ to the complex concentration, $A_{\text {obs }} /\left[\right.$ complex], and $\varepsilon_{\mathrm{b}}$ and $\varepsilon_{\mathrm{f}}$ are the extinction coefficients of the complex in the presence and absence of calf thymus DNA. The intrinsic binding constant $K$ can be calculated from the ratio of the slope to the $y$-intercept obtained from the linear plot of $D / \Delta \varepsilon_{\text {ap }} v s . D$.

\section{RESULTS AND DISCUSSION}

\section{Electronic Absorption Spectroscopy}

The electronic absorption spectra for the ruthenium(II) $\mathrm{N}^{\wedge} \mathrm{N}$ complex $\mathbf{1}$ is shown in Fig. 2, and its electronic absorption and the corresponding wavelength are recorded as following: $\lambda_{\text {abs }} / \mathrm{nm}$ ( $\left.\varepsilon / \mathrm{dm}^{3} \mathrm{~mol}^{-1} \mathrm{~cm}^{-1}\right) 256$ (61 340), 286 (53 935), 
340 (14 965), 430 (9915), 482 sh (7955). Strong absorption band at high energy is observed at 256 $\mathrm{nm}$ and is due to the intraligand (IL) transitions of the $\mathrm{N}^{\wedge} \mathrm{N}$ ligands as the free ligands, $N-(2-$ pyridylmethylene)-2-anthramine, while that at 286 $\mathrm{nm}$ is assigned as an admixture of ligand centred $\pi \rightarrow \pi^{*}$ transitions of the ancillary ligands (bipyridine) and the extended aromatic $\mathrm{N}^{\wedge} \mathrm{N}$ ligands. Absorption bands at 340 are due to the low energy components of the ligand centred $\pi \rightarrow \pi^{*}$ transitions. Based on previous spectroscopic studies on relative ruthenium(II) $\mathrm{N}^{\wedge} \mathrm{N}$ complexes, the absorptions at $430 \mathrm{~nm}$ are tentatively assigned as an admixture of $\mathrm{d} \pi(\mathrm{Ru}) \rightarrow \pi^{*}$ (bpy) MLCT and intraligand transition of the $\mathrm{N}^{\wedge} \mathrm{N}$ ligands. Shoulder peaks at $c a .482 \mathrm{~nm}$ are assigned to $\mathrm{d} \pi(\mathrm{Ru}) \rightarrow \pi^{*}\left(\mathrm{~N}^{\wedge} \mathrm{N}\right) \quad$ MLCT transition. When compared to the absorption bands that have been found in relative ruthenium(II) $\mathrm{N}^{\wedge} \mathrm{N}$ complexes, ${ }^{2}$ the change of components on the $\mathrm{N}^{\wedge} \mathrm{N}$ ligands has apparently little effect on the energies of the MLCT bands.

\section{Luminescence Properties}

Excitation of ruthenium(II) $\mathrm{N}^{\wedge} \mathrm{N}$ complex 1 in degassed acetonitrile solution at $\lambda>350 \mathrm{~nm}$ produces emission at $c a .790 \mathrm{~nm}$, as is shown in Fig. 3. Based on the previous assignment on the emission behaviour of ruthenium(II) $\mathrm{N}^{\wedge} \mathrm{N}$ complexes, ${ }^{8}$ the origin of this emission is assigned as the lowest triplet state MLCT that should be derived from the $\mathrm{d} \pi(\mathrm{Ru}) \rightarrow \pi^{*}\left(\mathrm{~N}^{\wedge} \mathrm{N}\right)$ MLCT transition. The transition energy is similar to that found in $\left[\mathrm{Ru}(\mathrm{bpy})_{2}(\mathrm{diN})\right]\left(\mathrm{PF}_{6}\right)_{2}$, where $\mathrm{diN}=$ other $\mathrm{N}^{\wedge} \mathrm{N}$ ligand, which usually luminesces at $c a$. 780$800 \mathrm{~nm}^{6}{ }^{6}$ The complex $\mathbf{1}$ has lower ${ }^{3}$ MLCT emission energy when compared to $\left[\mathrm{Ru}(\mathrm{bpy})_{3}\right]^{2+}$, which luminesces at $c a .615 \mathrm{~nm}$. This may be explained by the presence of low energy $\pi^{*}$ orbitals in the conjugated $\mathrm{N}^{\wedge} \mathrm{N}$ ligands. Therefore, the energy gap between the orbitals of $d \pi(\mathrm{Ru})$ and $\pi^{*}\left(\mathrm{~N}^{\wedge} \mathrm{N}\right)$ is smaller, leading to lower ${ }^{3} \mathrm{MLCT}$ emission energy as well as shorter lifetime.

\section{Electrochemical Properties}

The cyclic voltammograms for complex $\mathbf{1}$ show rich structures inacetonitrile solution with $0.1 \mathrm{~mol}$ $\mathrm{dm}^{-3}{ }^{n} \mathrm{Bu}_{4} \mathrm{NPF}_{6}$ as supporting electrolyte at room temperature with a scan rate of $100 \mathrm{mV} \mathrm{s}^{-1}$. As is shown in Fig. 4, there are one oxidation couples and four reduction couples. The oxidation $\mathrm{E}_{1 / 2}$ is $+1.34 \mathrm{~V} v$ s. S.C.E., and the reduction $\mathrm{E}_{1 / 2}$ are -1.08 $\mathrm{V},-1.50 \mathrm{~V},-1.75 \mathrm{~V},-1.95 \mathrm{~V}$ vs. S.C.E., in which $\mathrm{E}_{1 / 2}$ refers to $\left[\left(\mathrm{E}_{\mathrm{pa}}+\mathrm{E}_{\mathrm{pc}}\right) / 2\right]$ where $\mathrm{E}_{\mathrm{pa}}$ and $\mathrm{E}_{\mathrm{pc}}$ are the anodic and cathodic peak potentials, respectively. The oxidation couples at $+1.34 \mathrm{~V} v s$. S.C.E. with $\Delta \mathrm{E}_{\mathrm{p}}$ values of $c a .75 \mathrm{mV}$ are quasireversible in nature and are assigned as $\mathrm{Ru}(\mathrm{II})$ to $\mathrm{Ru}(\mathrm{III})$ oxidation. These oxidation potentials are close to those found in $\left[\mathrm{Ru}(\mathrm{bpy})_{2}(\mathrm{diN})\right]^{2+}(c a$. $+1.30 \sim+1.40 \mathrm{~V} v s$. S.C.E.), ${ }^{6}$ and are typical of these systems.

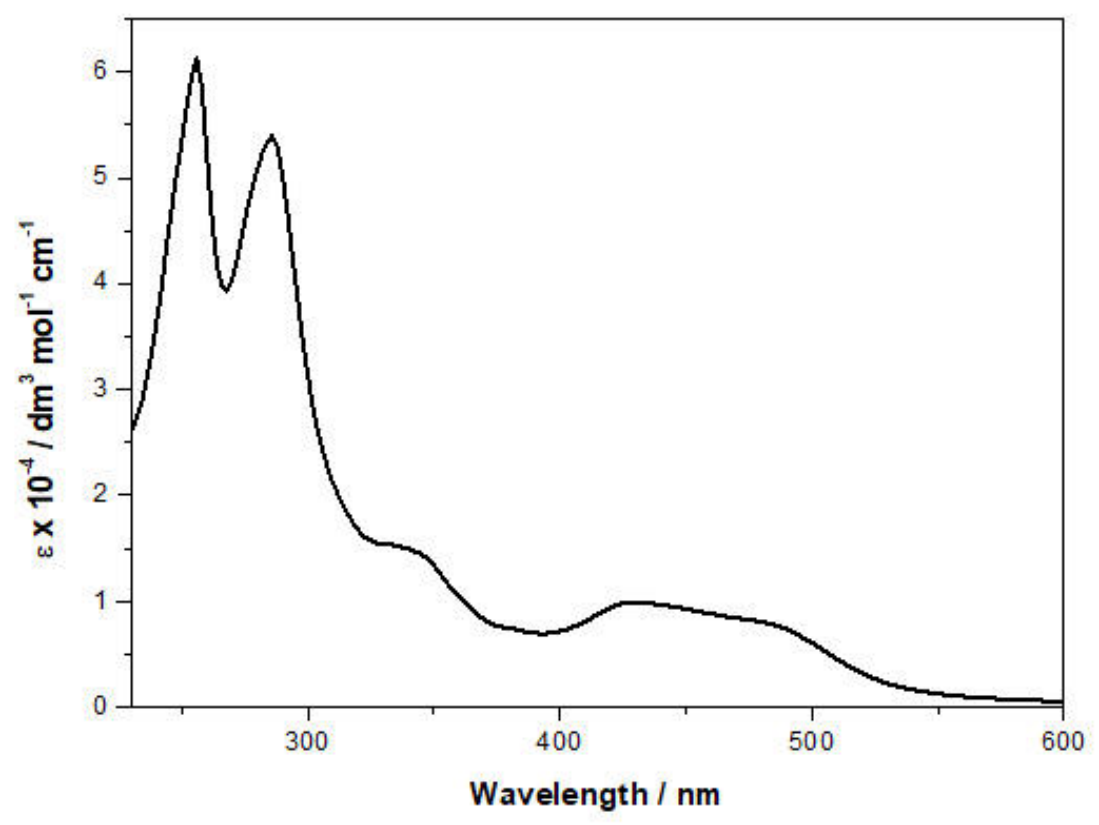

Fig. 2 - Electronic absorption spectrum of $\mathbf{1}$ in degassed $\mathrm{CH}_{3} \mathrm{CN}$ at $298 \mathrm{~K}$. 


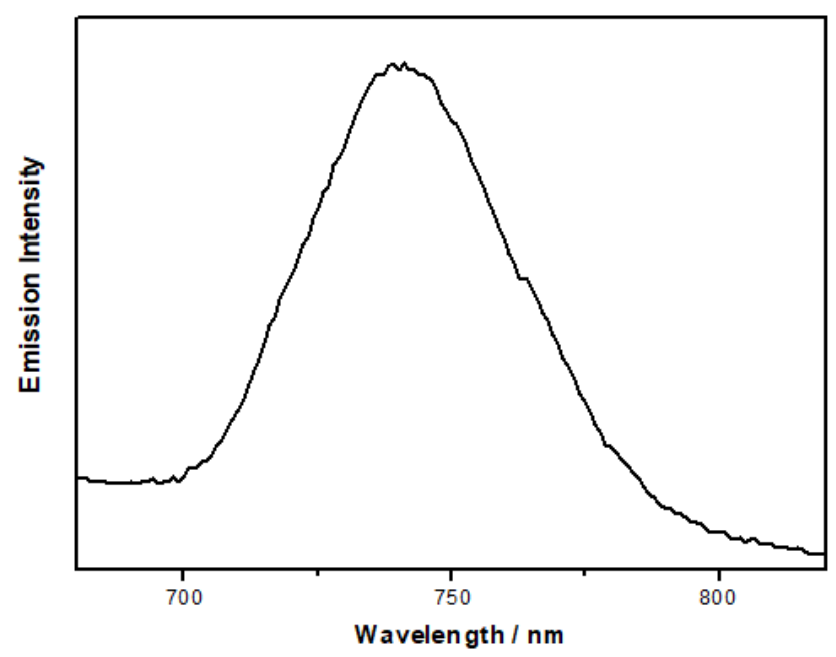

Fig. 3 - Emission spectrum of $\mathbf{1}$ in degassed $\mathrm{CH}_{3} \mathrm{CN}$ at $298 \mathrm{~K}$.
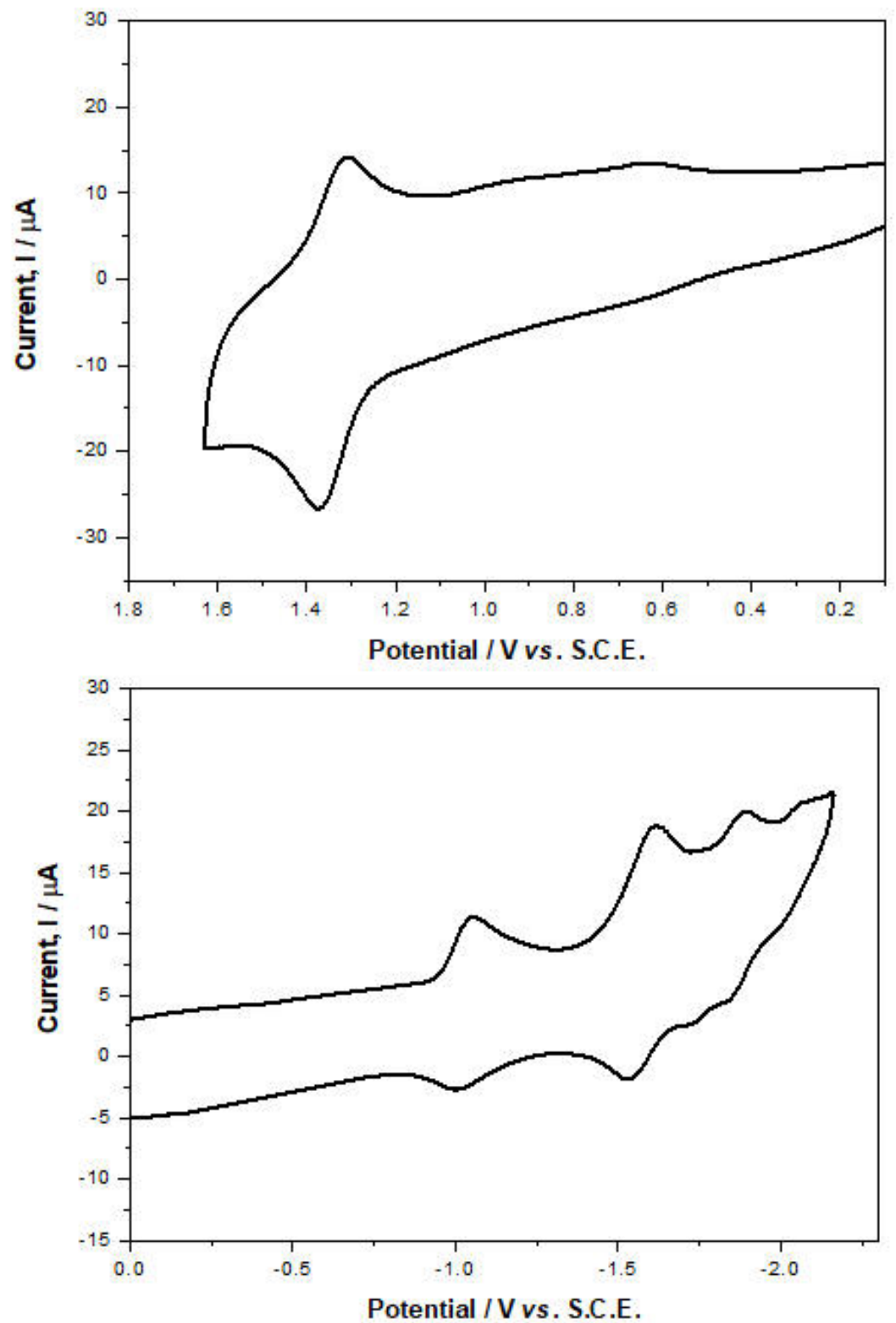

Fig. 4 - Cyclic voltammograms of $\mathbf{1}$ in acetonitrile $\left(0.1 \mathrm{~mol} \mathrm{dm}{ }^{-3}{ }^{n} \mathrm{Bu}_{4} \mathrm{NPF}_{6}\right)$. 


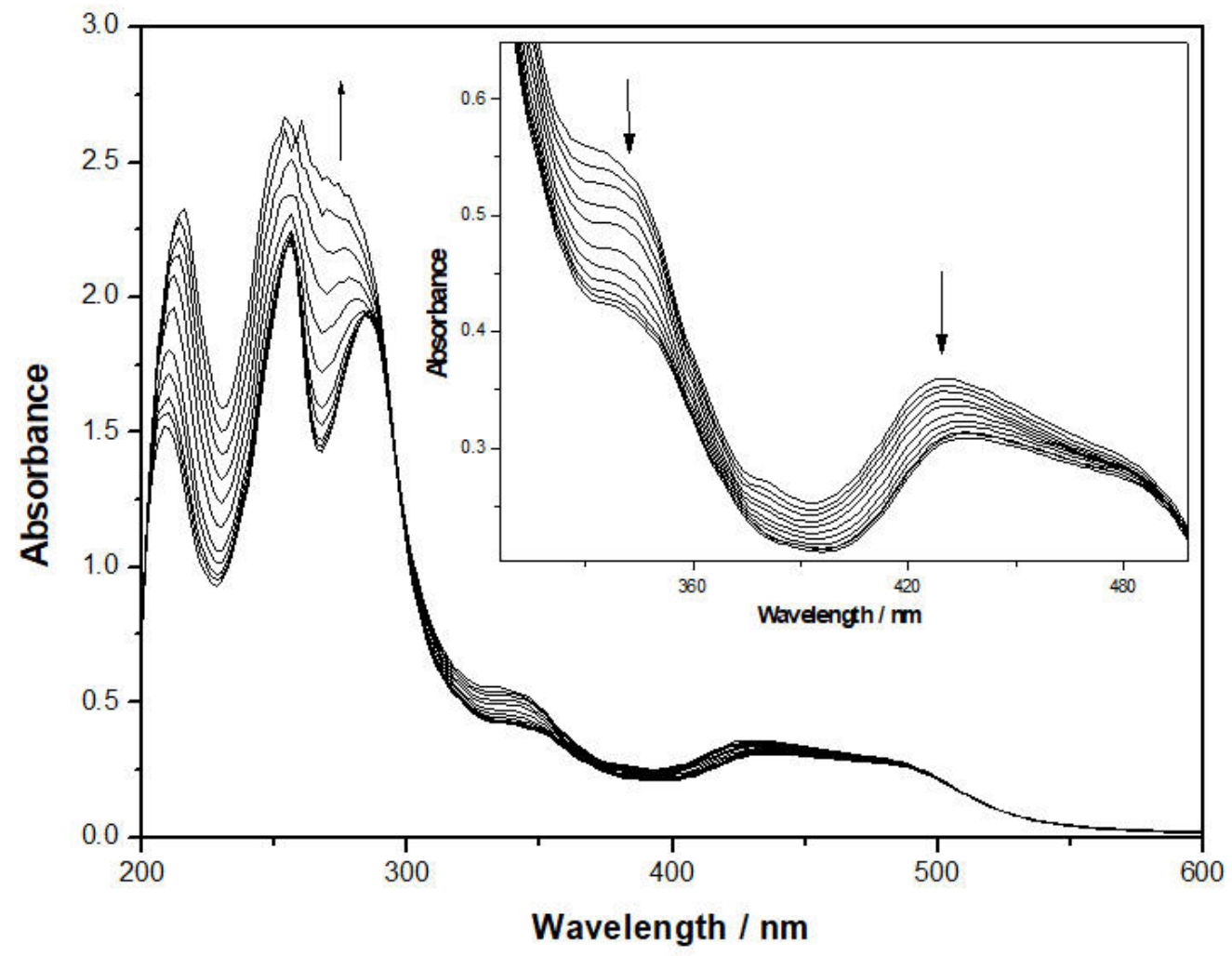

Fig. 5 - Electronic absorption spectral traces of 1 in $5 \%$ aqueous buffered $(20 \mathrm{mM}$ Tris-HCl, $\mathrm{pH} 7.0)$ methanolic solution upon addition of double-stranded calf thymus DNA. The insert shows an expanded portion of the spectrum for clarity purpose.

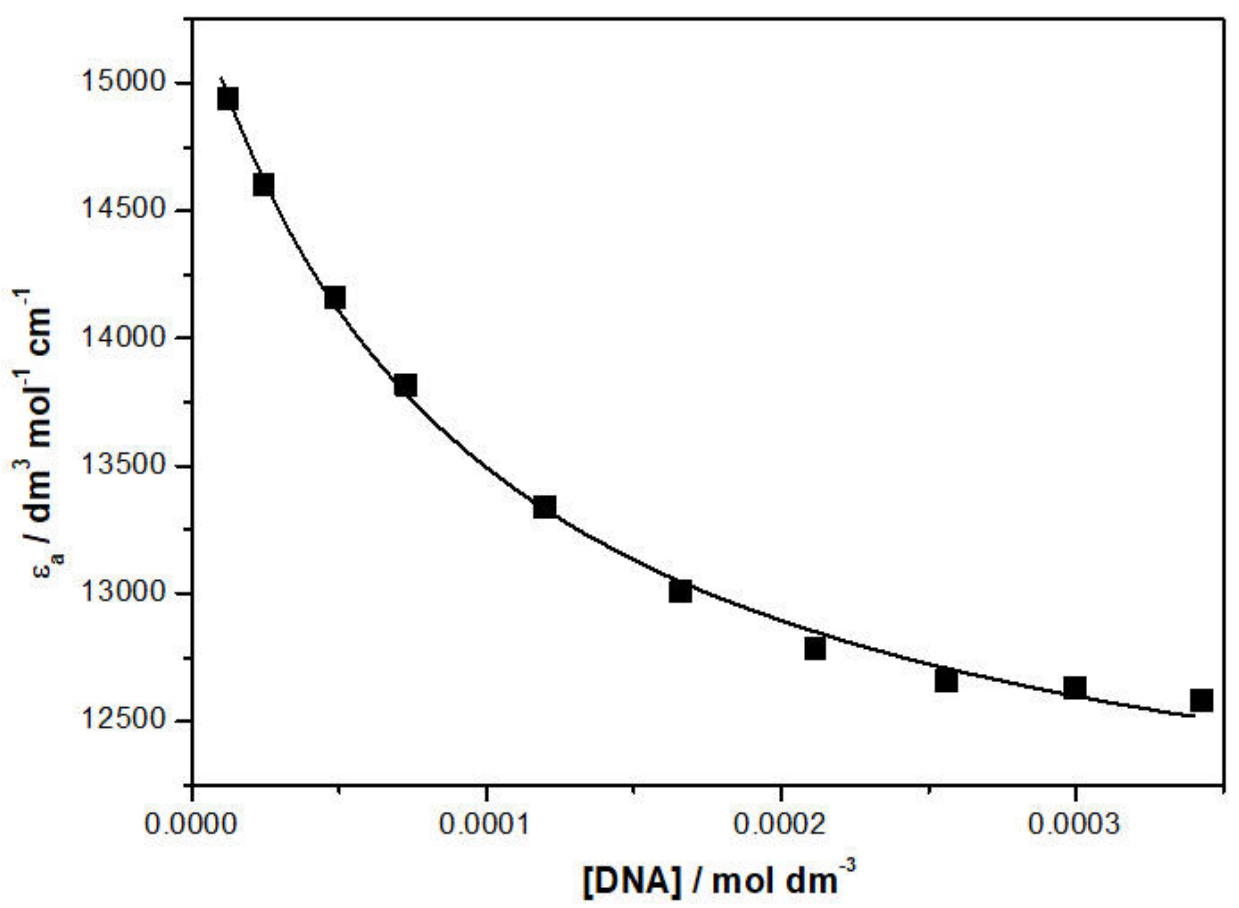

Fig. 6 - Plot of $\varepsilon_{\mathrm{a}} v s$. [DNA] for 1 with the wavelength monitored at $334 \mathrm{~nm}$. The solid line shows the theoretical fit according to equation (1). 


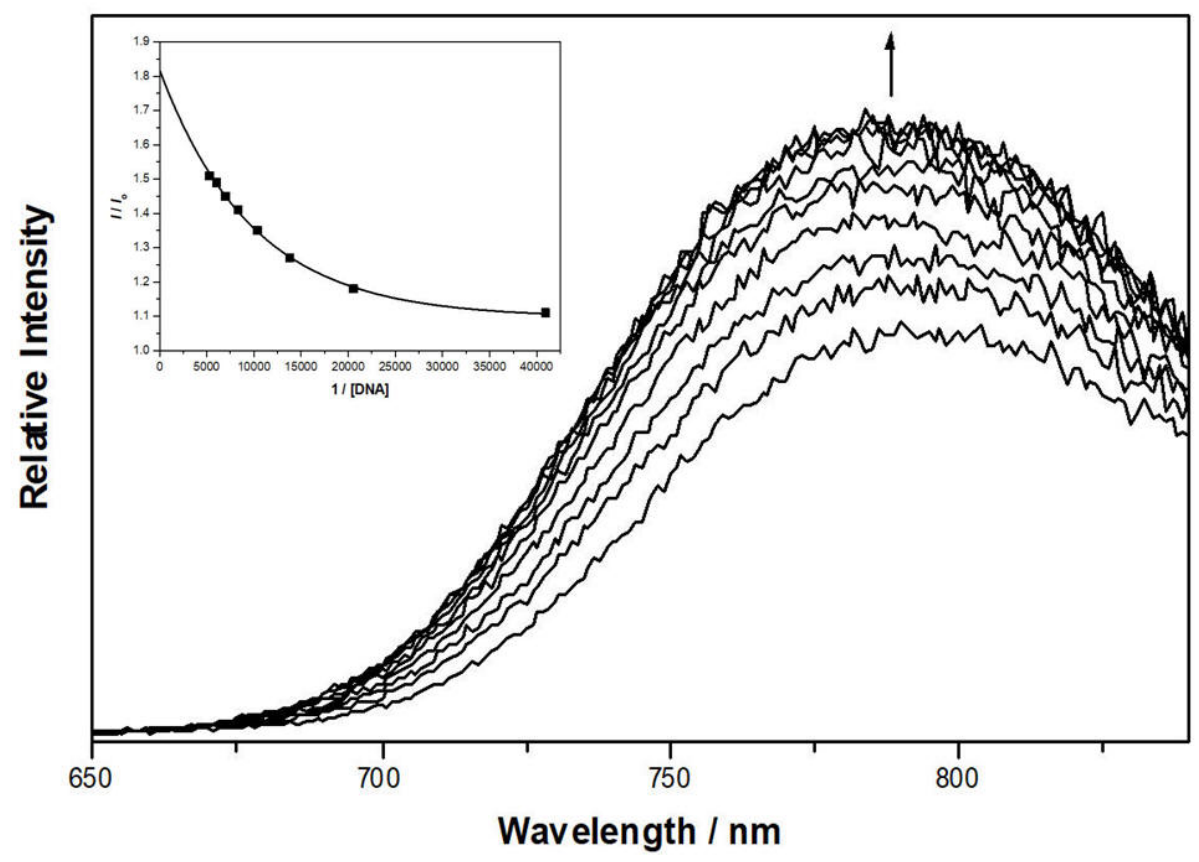

Fig. 7 - Emission spectral traces of 1 in aqueous MeOH/buffer (20 mM Tris-HCl, pH 7.0) at $298 \mathrm{~K}$ upon addition of double-stranded calf thymus DNA. The insert shows plot of $I / I_{\mathrm{o}} v s .1 /[\mathrm{DNA}]$ for the calculation of binding constant.

Based on the previous assignment on the reduction peaks of ruthenium(II) $\mathrm{N}^{\wedge} \mathrm{N}$ complexes, ${ }^{9}$ the reduction couples at $-1.08 \mathrm{~V}$ vs. S.C.E. are assigned as the reduction of the $\mathrm{N}^{\wedge} \mathrm{N}$ ligands, which are similar to those found in $\left[\mathrm{Ru}(\mathrm{bpy})_{2}(\mathrm{diN})\right]^{2+}(c a$. $1.0 \sim-1.10 \mathrm{~V} v$ s. S.C.E.). ${ }^{2,6}$ The reversible reduction couples at -1.50 and $-1.75 \mathrm{~V} v s$. S.C.E. are assigned as the successive reductions of the bipyridine ligands, which are commonly observed in other ruthenium(II) bipyridyl complexes. The first reduction potential of the bipyridine ligand which occurs at $-1.50 \mathrm{~V} v s$. S.C.E. is more cathodic than $-1.33 \mathrm{~V} v$ s. S.C.E. of $\left[\mathrm{Ru}(\mathrm{bpy})_{3}\right]^{2+}$. This can be explained by the increased electron donating ability from the reduced $\mathrm{N}^{\wedge} \mathrm{N}$ ligand as well as the reduced overall positive charge of the complex after one-electron reduction. With the presence of the extended aromatic moieties, the reduction couples at $-1.95 \mathrm{~V}$ vs. S.C.E. are considered as the second reduction of the $\mathrm{N}^{\wedge} \mathrm{N}$ ligands.

\section{DNA Binding Studies - Electronic Absorption Titrations}

The electronic spectral trace of complex $\mathbf{1}$ in $5 \%$ aqueous buffered methanolic solution upon addition of calf thymus DNA is shown in Fig. 5. And the corresponding plot of $\varepsilon_{\mathrm{A}}$ for complex $1 \mathrm{vs}$. [DNA] is shown in Fig. 6. In 5\% aqueous buffered (20 mM Tris-HCl, $\mathrm{pH}$ 7.0) methanolic solution of
1, pronounced hypochromism is observed in the $\mathrm{N}^{\wedge} \mathrm{N}$ IL band at $340 \mathrm{~nm}$ as well as in the $\mathrm{d} \pi(\mathrm{Ru}) \rightarrow \pi^{*}\left(\mathrm{~N}^{\wedge} \mathrm{N}\right)$ MLCT transitions at $430 \mathrm{~nm}$ upon addition of double-stranded calf thymus DNA (Fig. 5). The hypochromism could be due to a strong interaction between the electronic states of the intercalating chromophore and that of the DNA bases. Bathochromic shifts are also noticed upon addition of calf thymus DNA to the ruthenium $\mathrm{N}^{\wedge} \mathrm{N}$ complex, and this suggests the binding is most likely through a non-covalent intercalative mode. This also suggests that the intercalation of the $\mathrm{N}^{\wedge} \mathrm{N}$ ligand between the bases in the DNA double helix is more favoured than the introduction of bipyridine ligands, which might be related to the extended planar aromatic structure of the anthracene moiety in complex 1. The $\mathrm{A}_{\mathrm{o}} / \mathrm{A}$ ratio reaches a maximum of ca. 1.3 at $[\mathrm{DNA}] /[$ Complex] $~ 10$. The complex has an intrinsic binding constant of $1.06 \times 10^{4} \mathrm{dm}^{3}$ $\mathrm{mol}^{-1}$ to double-stranded calf thymus DNA.

\section{DNA Binding Studies - Emission Titrations}

For comparison, emission titration experiments have also been employed for the DNA binding studies. The luminescence spectral traces and the theoretical fits to the plots of $I / I_{\mathrm{o}}$ vs. $1 /[\mathrm{DNA}]$ are shown in Fig. 7. The emission intensity of the ruthenium(II) $\mathrm{N}^{\wedge} \mathrm{N}$ complex grows steadily upon addition of calf thymus DNA, and the increase of 
emission intensity reaches a maximum to indicate a completion for binding of the metal complex. The $\mathrm{I} / \mathrm{I}_{\mathrm{o}}$ value reaches a maximum at $c a .1 .5$ with the [DNA]:[Complex] ratio of ca. 6. The binding constant is thus determined to be $1.43 \times 10^{4} \mathrm{dm}^{3}$ $\mathrm{mol}^{-1}$, which is in agreement with that determined using absorption titration studies $\left(1.06 \times 10^{4} \mathrm{dm}^{3}\right.$ $\left.\mathrm{mol}^{-1}\right)$. The value is also comparable to that of other ruthenium(II) complexes, such as $\left[\mathrm{Ru}(\text { phen })_{3}\right]^{2+}\left(6.2 \times 10^{3} \mathrm{dm}^{3} \mathrm{~mol}^{-1}\right){ }^{10}$

\section{CONCLUSION}

A novel ruthenium(II) complex with extended aromatic moiety is prepared. Its electronic absorption and luminescence characteristics are well deduced as well as the electrochemical properties. The DNA binding affinities of the complex are monitored by the electronic absorption and emission spectroscopy. Hypochromism in absorption peaks is indicative of the intercalative binding mode, which has also been found in other complexes with planar aromatic structures. The intrinsic binding constants were small when compared to other metallointercalators with the dppz ligand. This was attributed to the difference in structural configuration and orientation of the aromatic moieties between different metallointercalators.
Acknowledgments. This work was supported by Natural Science Foundation of Jiangsu Province (BK20181211), Qinlan Project of Jiangsu Province (year 2019), Jiangsu Government Scholarship for Oversea Studies, Funds for the "515" Leading Talents of Innovation and Entrepreneurship of Yancheng City, and Funds from Jiangsu Vocational College of Medicine (20178108) (20166103).

\section{REFERENCES}

1. A. E. Friedman, J. C. Chambron, J. P. Sauvage, N. J. Turro, J. K. Barton, J. Am. Chem. Soc., 1990, 112, 4960.

2. J. D. Knoll, C. Turro, Coord. Chem. Rev., 2015, 283, 110.

3. H. J. Lozano, N. Busto, G. Espino, A. Carbayo, J. M. Leal, J. A. Platts, B. Garcia, Dalton Trans., 2017, 46, 3611.

4. X. W. Liu, J. S. Shu, Y. Xiao, Y. M. Shen, S. B. Zhang, J. L. Lu, J. Coord. Chem., 2015, 68, 2886.

5. Z. D. Bugarcic, Jovana Bogojeski, R. van Eldik, Coord. Chem. Rev., 2015, 292, 91.

6. D. L. Ashford, C. R. K. Glasson, M. R. Norris, J. J. Concepcion, S. Keinan, M. K. Brennaman, J. L. Templeton, T. J. Meyer, Inorg. Chem., 2014, 53, 5637.

7. B. P. Sullivan, D. J. Salmon, T. J. Meyer, Inorg. Chem., 1978, 17, 3334.

8. V. Goudy, J. Maynadie, X. L. Goff, D. Meyer, M. Fontecave, New J. Chem., 2016, 40, 1704.

9. S. Mardanya, S. Karmakar, D. Mondal, S. Baitalik, Inorg. Chem., 2016, 55, 3475.

10. J. K. Barton, A. T. Danishefsky, J. M. Goldberg, J. Am. Chem. Soc., 1984, 106, 2172. 
